\title{
Intermodal Line between Ploce and Brcko: Future Perspectives for the Pan-European Transport
}

\author{
$N$. Palic ${ }^{1}, E$. Velinov ${ }^{2,3}$, and $V$. Vassilev ${ }^{4}$ \\ ${ }^{*}$ Corresponding author: emil.velinov@savs.cz. \\ ${ }^{1}$ CEPS College "Center for business Studies", Kiseljak, Bosna and Hercegovina \\ ${ }^{2}$ Skoda Auto University, Mlada Boleslav, Czech Republic \\ ${ }^{3}$ RISEBA University of Applied Science, Riga, Latvia \\ ${ }^{4}$ University of Transport, Todor Kableshkov, Sofia, Bulgaria
}

\begin{abstract}
The aim of this paper is to propose the intermodal logistics Corridor Vc, relying on the European Union transport policy, which will be in the function of regional development. The main goal is to analyze a potential route of freight intermodal transport between the ports of Ploče and Brčko in order to popularize this intermodal line at the international level. Among the most important activities in achieving this goal is the integration in the Euro corridor system. This integration is of crucial importance for companies to successfully execute their supply chain processes both domestically and internationally. The paper is based on the analysis of the current socio-economic situation and the condition of the intermodal transport system in Bosnia and Herzegovina (BiH), as well as existing strategic studies and development plans. This paper sheds a light on the creation of a strong integrated intermodal freight transport network in $\mathrm{BiH}$, that will be a quality alternative to other international intermodal flows from the aspect of shorter transport time, lower transport costs and more favorable ecological aspects of transportation.
\end{abstract}

Keywords: intermodal, transport network, Bosna and Hercegovina.

\section{Introduction}

Bosnia and Herzegovina (BiH) is a land of extraordinary resources - both natural and human, but the synergy effect of their interaction is missing. There is a lack of cross-sectoral coordination in all key policy areas - regulatory, investment, fiscal, social, spatial, environmental and so on. Logic states that the regional organization at the national level and the local unit level is based on the recognition of spatial specifics, their development potential and functional integration. In addition to the uneven regional development, the problem for $\mathrm{BiH}$ is also the trend of mass emigration of the population to Western European countries. The response to these problems is to be found in the development of a quality and attractive intermodal logistics corridor, which will popularize the entire $\mathrm{BiH}$ area, stop the outbreak of population and thus contribute to better regional development.

Revitalization of key elements of the intermodal logistics corridor will contribute to the establishment of a competitive intermodal logistics route (Port Ploče - Corridor Vc - Port Brčko) at international level, thereby enhancing regional development in $\mathrm{BiH}$ and beyond. To prove this, it is necessary to evaluate the potentials of intermodal logistic Corridor Vc. During the valorization, a large source of secondary data was used to enhance the validity of the analysis that will be offered in the work: White Paper 2011 Strategy, TEN-T Network Development Strategy, Construction project "Highway in Corridor Vc", Intermodal Transport Study in Bosnia and Herzegovina, Strategy for Development of Air Traffic Management System in Bosnia and Herzegovina, Transport Master Plan Study in BiH (JICA, 2001), Project B.E.P.O. Neretva, Intermodal Transport System "Intercontainer", BiH Transport Strategy 2016-2030, projects with EU funds, papers from international scientific conferences etc.

First, the analysis of socio-economic data along the route of the Corridor Vc was carried out. The geopolitical importance of the Corridor Vc was highlighted, where an influential corridor zone was presented and a Framework plan for optimization of the intermodal logistics corridor was offered throughout $\mathrm{BiH}$. In the last chapter, the valorization of the intermodal logistics corridor $\mathrm{Vc}$ was done by comparing the potential revitalized route through $\mathrm{BiH}$ with already existing international intermodal routes. The key criteria to be taken into consideration are transport time, transport costs and ecological aspects of the transport process. If these criteria prove to be more efficient, it would be justified to invest in key elements of the intermodal logistics corridor. The revival of this framework would contribute to regional development in $\mathrm{BiH}$ and beyond.

\section{Analysis of socio-economic data along the route of corridor Vc and cohesion potential}

During the analysis socio-economic socio-economic data it is especially important that the geo-traffic position of the specific area is valorized in the context of its territorial and functional affiliation to a wider region at the transregional 
and national level, and following the elaboration of development projections ensure integration into the competitive European macro-region.

Table 1: Share of urban and rural populations by European regions / countries

\begin{tabular}{|c|c|c|c|c|}
\hline Region/State & Urban population & Share (\%) & Rural population & Share (\%) \\
\hline Europe & 533.295 .008 & 72,8 & 199.463 .538 & 27,2 \\
\hline East Europe & 200.938 .427 & 68,9 & 90.546 .160 & 31,1 \\
\hline North Europe & 1.827 .955 & 79,1 & 20.691 .418 & 20,9 \\
\hline West Europe & 149.930 .742 & 79,5 & 38.656 .465 & 20,5 \\
\hline South Europe & 104.208 .508 & 67,8 & 49.569 .495 & 32,2 \\
\hline Bosnia and Herzegovina & 1.827 .955 & 48,6 & 1.931 .678 & 51,4 \\
\hline Region of Corridor Vc ${ }^{*}$ & 846.407 & 40,51 & 1.243 .160 & 59,49 \\
\hline
\end{tabular}

Source: Own elaboration based on Geohive."Urban/rural division of countries for the years 2015 and 2025." Geohive. Accessed, January 7, 2017 [1]. Authors calculations on the basis of NASBIH (http://nasbih.com/), June, 2016

By analyzing the statistical data of the urban-rural population structure in Europe, there are significant differences between $\mathrm{BiH}$ and the corresponding territorial unit of Southern Europe, and even more so in relation to the urban-rural structure of the populations of the regions of Northern and Western Europe.

$\mathrm{BiH}$ has two urban centers with more than 100.000 inhabitants - Sarajevo and Banja Luka. However, when we look at the aspect of the municipality, then we can mention at least four more centers here: Tuzla, Zenica, Bijeljina and Grad Mostar, which together with the surrounding area and the formerly mentioned urban centers form agglomerates with about 1 million inhabitants or $24 \%$ of the total population (Figure 1 ).

For our research it is especially important to carry out an analysis of the area through which passes the route of Corridor Vc: Herzegovina-Neretva Canton (HNK 207), Sarajevo Canton (KS 209), Zenica-Doboj Canton (ZDK 204), Doboj Region (RD 212) and Brčko District (BD „A“), and areas of significant value: Central Bosnia Canton (SBK 206) and Banja Luka Region (RBL 211). This analysis will be done by applying the criterion of population share in the new typology of spatial units NUTS3 (Table 2).

For comparison, in Europe, $40.3 \%$ of the population lives in urban areas, $35.6 \%$ in transition regions and $24.1 \%$ of the population in rural areas (EU27, 2011.). By analyzing the statistical data, a significant deviation of the urban-rural distribution of the population of this part of $\mathrm{BiH}$ can be determined in relation to the average of the European Union over twice as small a population belongs to the urban category, and more than twice the category of rural population. Sarajevo Canton only belongs to the category of mostly urban areas $(82.9 \%)$, while the HNK and the Banja Luka Region can be sorted into the category of transition areas.

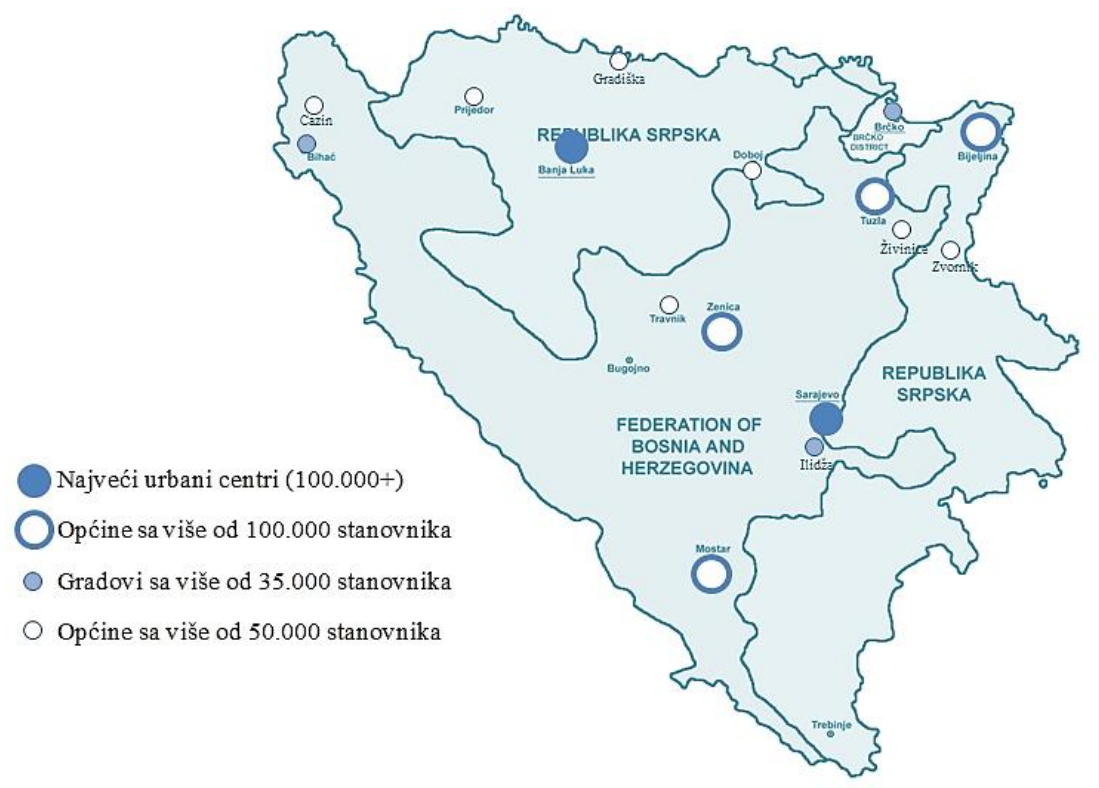

Fig. 1: Urban agglomerations and cities in $\mathrm{BiH}$ (left); Distribution of Regions / Cantons in BiH (right)

Source: Authors, based on data provided by the Agency for Statistics of Bosnia and Herzegovina, Population, Household and Housing Census in Bosnia and Herzegovina, 2013, Sarajevo, June, 2016 [2]

In the southern area of $\mathrm{BiH}$, namely in the $\mathrm{HNK}$, population density is 53.69 inhabitants per square kilometer, and in the central part - Canton Sarajevo, ZDK and SBK, population density is 140.43 inhabitants per square kilometer area and in the north - Doboj Region, Banja Luka and Brčko District, population density is 59.98 inhabitants per square kilometer area. It can be concluded that the population density is twice as high in the central part of $\mathrm{BiH}$, which is also 
the focal point of development. These indicators show that it is necessary to work on the popularization of other parts of the region in order to evenly distribute the development and thereby stimulate migration of the population and reduce the emigration, which could be greatly contributed by the implementation of the Corridor Vc. These data are indicative in the planning and programming of national development strategies, especially in the bases for redefining the regional organization of $\mathrm{BiH}$ and regional territorial cooperation.

Table 2: The share of urban and rural areas in $\mathrm{BiH}$ in the area of Corridor Vc according to the new NUTS3 typology (2013)

\begin{tabular}{|c|c|c|c|c|c|c|c|}
\hline Canton/Region & $\begin{array}{c}\text { Total } \\
\text { population }\end{array}$ & $\begin{array}{c}\text { Predominantly } \\
\text { urban }\end{array}$ & $\begin{array}{c}\text { Share } \\
\mathbf{( \% )}\end{array}$ & Intermediate & $\begin{array}{c}\text { Share } \\
(\%)\end{array}$ & $\begin{array}{c}\text { Predominantly } \\
\text { urban }\end{array}$ & $\begin{array}{c}\text { Share } \\
(\%)\end{array}$ \\
\hline HNK & 236.278 & 0 & 0 & 118129 & 49,99 & 118149 & 50,01 \\
\hline SBK & 273.149 & 0 & 0 & 49.298 & 18 & 223.851 & 82 \\
\hline KS & 438.443 & 363.314 & 82,9 & 0 & 0 & 75.129 & 17,1 \\
\hline ZDK & 385.067 & 0 & 0 & 115.134 & 29,9 & 269.933 & 70,1 \\
\hline RD & 226.523 & 0 & 0 & 0 & 0 & 226.523 & 100 \\
\hline RBL & 437.079 & 0 & 0 & 200.532 & 45,9 & 236.547 & 54,1 \\
\hline BD & 93.028 & 0 & 0 & 0 & 0 & 93.028 & 100 \\
\hline TOTAL & 2.089 .567 & 363.314 & 17,38 & 483.093 & 23,12 & 1.243 .160 & 59,49 \\
\hline
\end{tabular}

Source: Authors

Analyzing socio-economic indicators, there are significant differences in the status of the regional units of $\mathrm{BiH}$ that will be covered by the Corridor Vc in the rates of unemployment and the level of income. For example, the areas within the Vc corridor (HNK, ZDK, SBK and RD) reach a share of $40-50 \%$ of unemployment (The unemployment rate was determined on the basis of data on the number of unemployed by municipalities in relation to the labor force (employed + unemployed). Unemployment rate indicators by $\mathrm{BiH}$ regional units to a large extent coincides with the indicator of the level of income of the employed population, which has the smallest size in the observed area (ZDK, SBK, RD and RBL).

According to the recent census of $2013, \mathrm{BiH}$ has $14,07 \%$ of the population without any and with incomplete primary education; $21.4 \%$ of the population has completed elementary school; $51.1 \%$ secondary school; $3.2 \%$ vocational school; and $9.6 \%$ higher education schools/universities.

The region of Central and Northern $\mathrm{BiH}$ as a predominantly rural area (SBK, ZDK, RD, BD) has an extremely unfavorable status, expressed in the size of the low educated population, reaching $75 \%$ in the total population over the age of 15. This data is also associated with an indicator of the age structure of the population, from which it is evident that the area of Central and Northern BiH has a median age of 35-44 years. This tells us that this is the area with the predominant population that is in full work force.

\section{Analysis of Intermodal Logistic corridor Vc}

The main function of the transport system is to insure area integration and social cohesion, as well as economic (market) integration. Competitive transport systems have a fundamental importance for Europe's competitiveness in the world, for economic growth, for job creation and for the quality of everyday life of people. While transport improvements have the potential to yield significant economic benefits, the regional distribution of these benefits is dependent on the level of transport costs. In order to keep low transport costs, we need to have an operational and wellconnected intermodal corridor. That kind of corridor will be suggested in this paper as an alternative to already existing international routes. The main idea is that goods from Asia flowa through Suez and continues from the Port of Ploce across the Corridor Vc by rail to Port Brcko and further to Port Vukovar, where the Danube and other goods routes go to Central and Western Europe, eg Rotterdam, Frankfurt, Praha, Wien, Bratislava, Budapest etc.

In Bosnia and Herzegovina (BiH), the main route of intermodal transport corridor should be acceros the Corridor Vc within the Trans-European-Network which runs in the middle part of the country passing through the most favorable conditions - the valleys of the Bosna and Neretva rivers, main railway network and the capital city Sarajevo. Corridor Vc has a strategic position in the European transport system and an ideal geotraffic location, making the connections between the countries of Central Europe, starting from Budapest to the south, through Sarajevo, and to the Adriatic Sea. Because of the proximity of the river Sava and the Danube it allows further connection with the Black Sea, but also with Turkey, providing a good basis for the development of intermodality in the South East European region. By completing all the components of the Vc corridor, it will represent the link between North, Central and Eastern Europe with Southern Europe, which is why the corridor has a great value in the economic and traffic integration processes of the Central European Space. However, the key importance for the development of economy and intermodality in this region has the entry point of the intermodal corridor that accepts goods from overseas countries (Asia and Africa), which is Port Ploče. 


\subsection{Influential (gravitational) corridor zone}

Given the spatial and temporal availability, where an average of 30 minutes is needed to overcome the distance of $30 \mathrm{~km}$, an influential (gravitational) zone of Corridor Vc (Figure 3 - in the middle) has been determined. [3]

This zone occupies less than $20 \%$ of $\mathrm{BiH}$ territory, where $56 \%$ of the population is inhabited, and $59 \%$ of the total number of employees, accounting for almost $63 \%$ of the state's GDP. It covers parts of the HNK, SBK, Sarajevo Canton and ZDK, Doboj Region i Brčko District. In addition, 61 municipalities are in this zone. It runs through four of the six largest centers in $\mathrm{BiH}$, including one of the two urban centers (Sarajevo, the capital). There are many important business facilities where is also located the largest road and rail node.

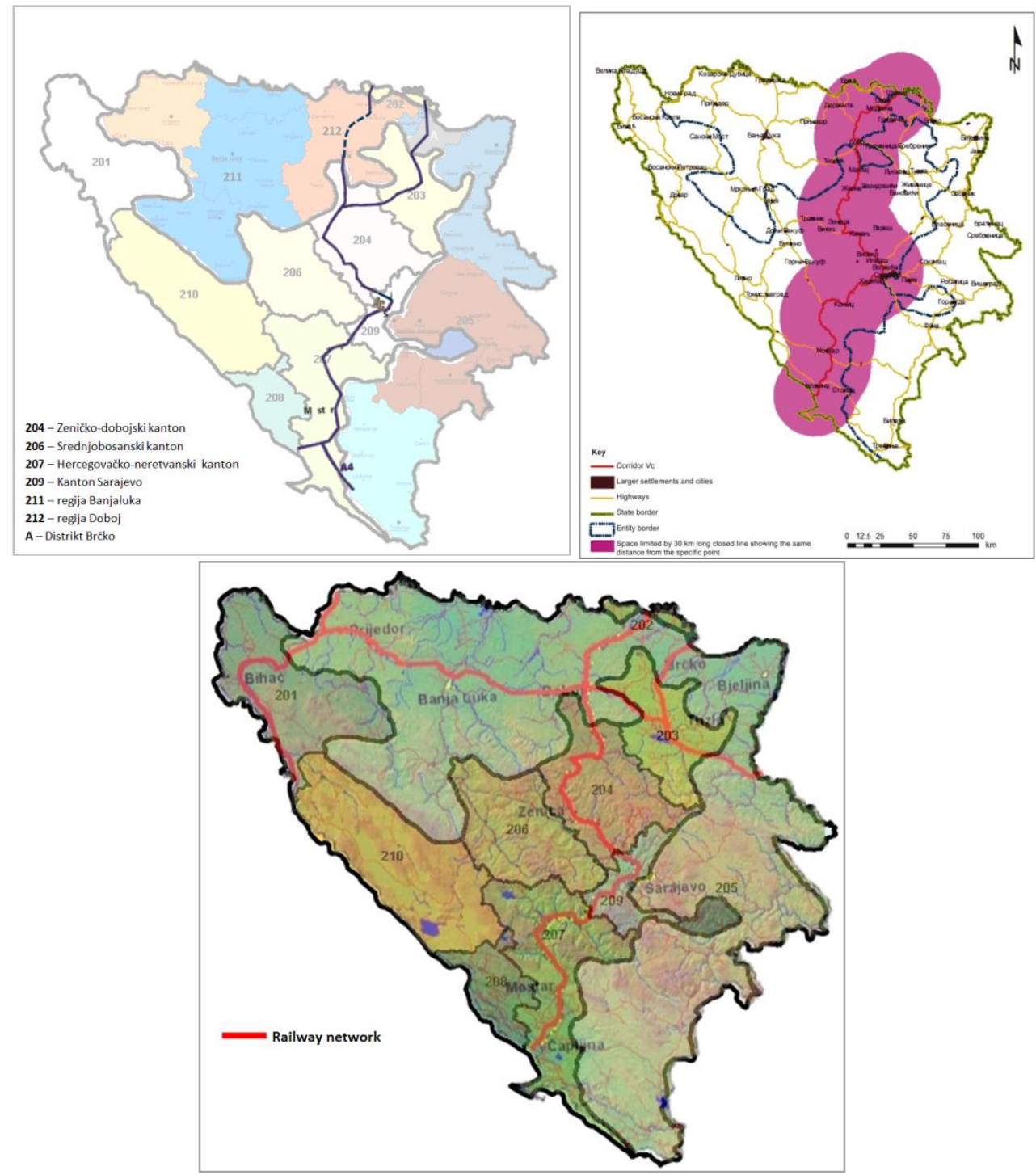

Figure 3: The route of Corridor Vc (left), influential (gravitational) zone of Corridor Vc (in the middle) and railroad

Source: Authors. network (right)

\subsection{Strategic plan for optimization of the intermodal logistics corridor Vc}

In order for this intermodal corridor to experience the maximum potential in the regional development of $\mathrm{BiH}$, it is necessary to optimize the specific points of the logistic intermodal corridor. The main goal is to take over part of goods flows from Asia and India to the central and western part of Europe, which is passing through the Suez Canal. The framework plan for optimizing the intermodal logistics corridor is given in Table 3. Listed activities are already part of existing development strategies mentioned in the introduction. Activities are mostly based on modernization of intermodal lines (especially the railway network and inland waterways) and nodes (Port Ploče, Sarajevo and Port Brčko to Vukovar). In order to attract the interest of freight forwarders who manage international goods flows to streamline the goods flow through the intermodal corridor through $\mathrm{BiH}$, it is most important to adequately equip the entry point of Corridor Vc, which in this case is Port Ploče. 
Table 3: Framework plan for optimization of the intermodal logistics corridor 2016-2030

\begin{tabular}{|c|c|c|c|}
\hline Activities in the period 2016-2030. & $\mathbf{2 0 1 6 - 2 0 2 0}$ & $\mathbf{2 0 2 0 - 2 0 2 5}$ & $\mathbf{2 0 2 5 - 2 0 3 0}$ \\
\hline Modernization of Port Ploče & & & \\
\hline Modernization of railroads in BiH & & & \\
\hline Modernization of Port Brčko & & & \\
\hline Adaptation of main intermodal nodes in BiH & & & \\
\hline Establishment of the operators and application of ICT & & \\
\hline Taking over part of the goods flows from Asia and India & & & \\
\hline
\end{tabular}

Source: Authors

Linking Port Ploče with the quality transport infrastructure of Corridor Vc with Corridor VII is a prerequisite for the extension of the Port Ploče gravitational area. In order to have that quality transport infrastructure we need to invest in the railway system from Ploče to Vukovar and to the Sava-Danube canal to connect the European Union with the most acceptable modes of transport from the point of view of costs, energy efficiency, ecology and safety: railroads and inland waterways.

By constructing a multipurpose channel Danube - Sava and Pan - European Corridor Vc (Budapest - Osijek Sarajevo - Ploče), Port Ploče will gain importance in combined and intermodal transport with all the Danubian countries as well as the western part of Europe through the Rhine - Main - Danube channel. The central Adriatic sea link and natural extension of the Vc corridor will trough Port Ploče connect the southern region of Italy with the countries of Central and Eastern Europe to the most economically acceptable way, with better conditions for achieving intermodality in freight transport [4].

Project Implementation of the Park B.E.P.O. Neretva that was designed by the Port Ploče Administration and the Shipping Institute of Zagreb could also contribute to the strengthening of Port Ploče. It is a business zone located in the Neretva valley with an ideal geostrategic location through which passes the Corridor Vc. One of the first strategic goals of this project is to initiate a sustainable economic development of the region within the radius of about $50 \mathrm{~km}$ on a geographical area that belongs to the Republic of Croatia and $\mathrm{BiH}$ [5].

However, the entry point in the intermodal corridor is not sufficient to redirect the flow of goods through the Corridor Vc. It is necessary to have a connected complete chain, which in this case can be achieved by modernizing the routes through $\mathrm{BiH}$. The first thing to do is adjust the railway network according to the South-east Europe Transport Observatory SEETO standards, and thus join the paths of „Intercontainer“, one of the most important systems of intermodal transport in South East Europe. It is also necessary to adapt certain intermodal nodes through $\mathrm{BiH}$, thinking primarily on the largest urban center of $\mathrm{BiH}$, which is the capital city Sarajevo. Sarajevo is the optimum choice for building a modern logistics center from more influential factors, for example due to the highest volume of goods flow in the country in this part, the largest population in this geographical area, the existence of an international airport nearby, the vicinity of the Ploče Doboj railway line and the influential corridor zone Vc passing through the industrial zone of the city [4]. Contribution to the development of the region and the popularization of this corridor would be improved by enabling the Tuzla airport with greater capacity for freight transport. Tuzla is also interesting because of the fact that the in Tuzla's railway junction faces the lines from Serbia over Zvornik and from Doboj with the connection to Corridor Vc. This position on the railway network offers great opportunities in the area of rail transport. This also applies to Banja Luka.

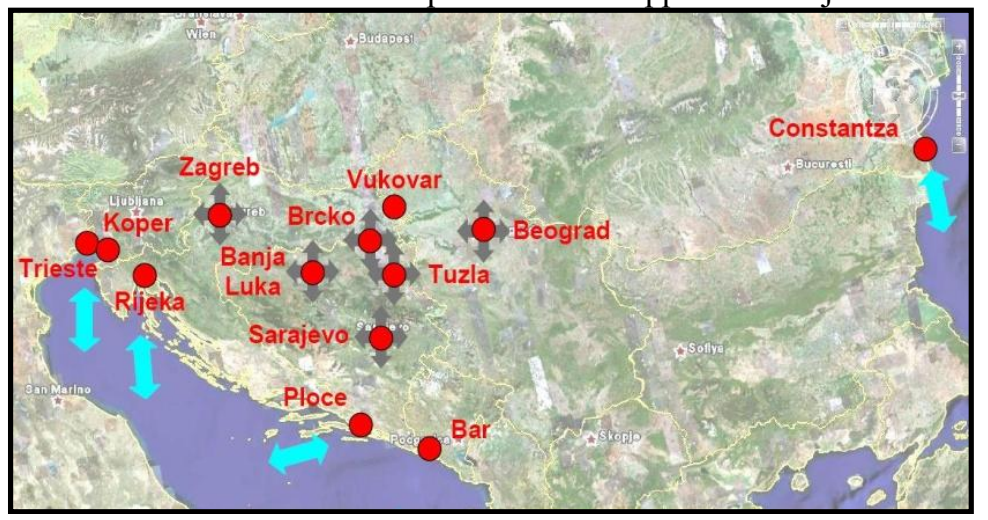

Fig. 4: Influential zone of Park B.E.P.O. Neretva and potential intermodal nodes through BiH and region Source: Own elaboration with the support of Google Maps API

The exit point from $\mathrm{BiH}$ and the entry into EU countries is Port Brčko, which in addition to the fact that it is located on Corridor Vc, can become a consolidation site for container flows that are coming from the East to BiH and further to the whole region [7]. Thus, Port Brčko has the potential to become the main container center in South East Europe [8].

The establishment of operators with strong ICT support would provide a rational division of labor market, concentration of commodity work and warehouse subsystems, coordination and cooperation of work by selecting the best carrier of transport in the macro distribution and concentration of activities with the unique service of urban areas 
and industrial zones in micro distribution, with the compatibility of ICT technology in all parts of the transport chain [9]. The last precondition is the establishment of a favorable system of the Schengen Border regime and the functional transboundary movement of people and goods, which would remove all barriers and open the door to trade flows through this corridor.

\section{Valorization of Intermodal logistic corridor Vc}

Valorization of the proposed intermodal logistics corridor Vc will be presented through comparison of the potential route through $\mathrm{BiH}$ with already existing international routes (Suez-Rotterdam-Frankfurt, Suez-Trieste-FrankfurtRotterdam, Suez-Constanta-Wien-Frankfurt-Rotterdam).

Since economic criteria (the power of receptive markets, transport costs, time savings, etc.) and environmental protection criteria (the release of poisonous gases into the atmosphere) are now almost decisive in making entrepreneurial and consumer decisions, data on distances, transport costs and emission of harmful substances are taken into considiration. Data are collected and processed for a number of possible travel routes for several cities in Central, North and Western Europe, which are inevitable in making decisions for every reasonable seller and buyer.[10]

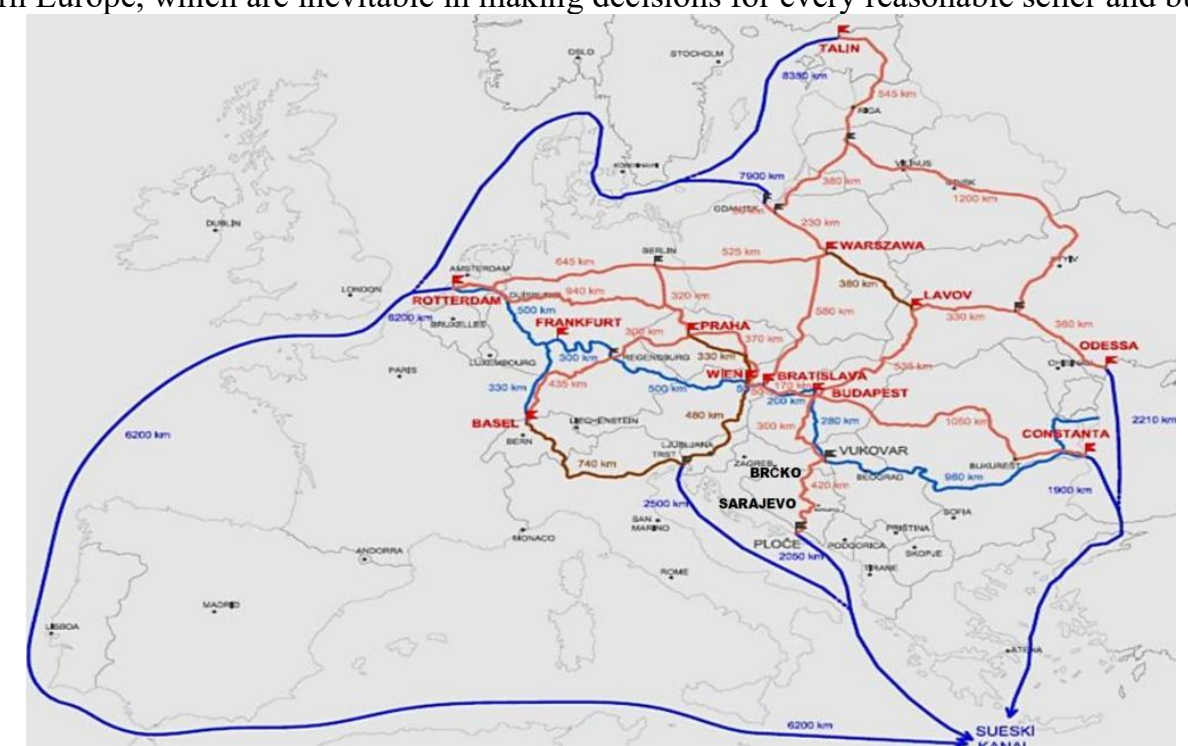

Fig. 5: Display of the distances of certain cities of Europe from Suez Source: Authors.

Calculations of route distance, done according to the Figure 5 are shown on Figure 6 (left). In order to calculate transport costs we have used the recommendations about energy consumption costs by different modes (the value of the transport cost of 1000 tons of goods). The results are also shown on Figure 6 (right). More detailed analysis is shown in the ANEX 1. It can be seen that directing goods flows through the intermodal logistics corridor Vc will shorten transport time and also reduce transport costs. We can conclude that the revitalization of the intermodal logistics Corridor Vc, made according to the proposed Framework Plan (Table 3), is much more acceptable than lot of other existing routes, and therefore justified.

Using the ship (across the sea and river) and the railway transport in relation to road transport, more than noticeable efficiency in environmental protection is achieved, which is in accordance with one of ten goals of White Paper transport policy: „Thirty per cent of road freight over $300 \mathrm{~km}$ should shift to other modes such as rail or waterborne transport by 2030 , and more than $50 \%$ by 2050 , facilitated by efficient and green freight corridor" [11].
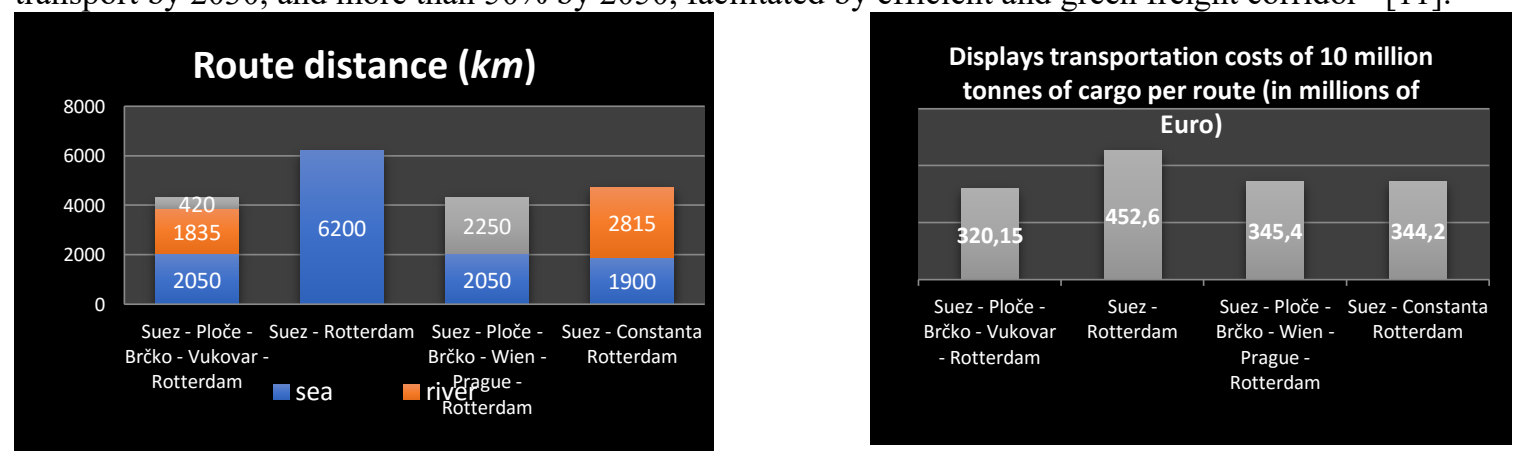

Fig. 6: Route distance (upper); Transportation costs of 10 million tonnes of cargo per route (lower) Source: Aurhors. 


\section{Conclusion}

The planning of an intermodal logistic corridor with supporting operational logistical and distribution terminals, investment prioritization of the use of existing corridor capacities of the regional transport network and affirmation of the transport function of natural resources and ecologically acceptable transport options are necessary frameworks of transport policy in relation to the requirements of sustainable development - economic growth, ecological equilibrium and social progress [12]. In the context of regional development, it is necessary to re-evaluate the pan-European transport corridor $\mathrm{Vc}$ and, through the combined instruments of cohesion policy, to devise a unique development strategy for the participating regions, taking into account the set thematic objectives and investment priorities of the common strategic framework, the national development strategy, the partnership agreement and operational programs and territorial cooperation program. In this spirit, the Framework Plan for the Optimization of the Intermodal Logistic Corridor Vc has been proposed, whose chronologically stated activities are already part of existing development strategies. By valuing and comparing with other alternative goods flows, it has been established that this intermodal logistic corridor would have great advantages over existing routes, reflected in shorter transport times, lower transport costs and environmentally acceptable results. We can conclude that revival of the suggested framework of intermodal logistic Corridor Vc has the potential to contribute regional development in $\mathrm{BiH}$ and beyond.

\section{References}

1. Geohive, Urban / rural division of countries for the years 2015 and 2025 (2017). URL: http://www.geohive.com/earth/pop_urban.aspx. Accessed: 07.01.2017.

2. Agency for Statistics of Bosnia and Herzegovina, Population, Household and Housing Census in Bosnia and Herzegovina, 2013, Sarajevo, June. URL: http://www.popis.gov.ba/popis2013/mapa/?lang=eng. Accessed: 20.09.2019.

3. M. Đuro, Corridor, VC as a factor of integration of Bosnia and Herzegovina into the European Union. Zbornik Radova: Geografski Institut "Jovan Cviji ć", 62(1), 89-101 (2012).

4. M. Martinovic, Povezivanje riječnog i pomorskog prometa u europskim lukama. Diss. University of Split. Master's thesis. University of Split (2017).

5. Foreign Investment Promotion Agency of Bosnia and Herzegovina, HIPP Group plans to build a plant in the Valley of Neretva (2014). URL: http://www.fipa.gov.ba/novosti/vijesti/default.aspx?id=5824\&langTag=en-US. Accessed: 20.09.2019.

6. H. Pilko, D. Majcan, Ž. Šarić, G. Zovak, Turbo roundabouts: Case study of Croatia. In I. Bajor, A. Vidović (Eds.) Proceedings of the International Scientific Conference "Science and Traffic Development" (ZIRP 2018) (pp. 221229). Zagreb: Faculty of Transport and Traffic Sciences University of Zagreb (2018).

7. S. Steiner, Air transport development potential in surroundings of Port Ploče. In S. Steiner, V. Koroman, J. Božičević, J.Z. Blašković, M. Nikšić, N. Brnjac (Eds.), Valorisation of the Intermodal Logistics Corridor PločeMostar-Sarajevo-Vukovar (Middle Adriatic - Danube Region) (pp. 63-74). Zagreb: Croatian Academy of Sciences and Arts (2014).

8. T. Rožić, M. Petrović, D.Ogrizović, Container transport flows as a prerequisite for determination of inland terminal location. Pomorstvo, 28(1), 3-9 (2014).

9. V. Roso, N. Brnjac, B. Abramovic, Inland intermodal terminals location criteria evaluation: The case of Croatia. Transportation Journal, 54(4), 496-515 (2015).

10. M. Muschkiet, Binnenschiffgüterverkehr. In U. Clausen, C. Geiger (Eds.) Verkehrs-und Transportlogistik (pp. 179202). Berlin, Heidelberg: Springer (2013).

11. P. Golinska, M. Hajdul, European Union policy for sustainable transport system: Challenges and limitations. Sustainable Transport, 3-19. Berlin, Heidelberg: Springer (2012).

12. V. Vassilev, E. Velinov, Monitoring and evaluation of quality in rail transport services: An element of quality management. Serbian Journal of Engineering Management, 2(1), 1-7 (2017). 